\title{
Pengaruh Karakteristik Individu Dan Leadership, Terhadap Kinerja Organisasi Dengan Teamwork Sebagai Variabel Intervening Pada Puskesmas Terakreditasi Paripurna Di Kabupaten Pasuruan
}

\author{
Mira Kurniawati ${ }^{1}$ \\ Departemen Manajemen, STIE Malangkucecwara \\ Malang, Indonesia, mirahilman07@gmail.com \\ Lidia Andiani2 \\ Departemen Manajemen, STIE Malangkucecwara \\ Malang, Indonesia, lidia@stie-mce.ac.id \\ Hanif Mauludin ${ }^{3}$ \\ Departemen Manajemen, STIE Malangkucecwara \\ Malang, Indonesia, hanif@stie-mce.ac.id
}

\begin{abstract}
Background - Based on the observations of researchers while being an accreditation companion at a fully accredited health center, several components of the success of the puskesmas in getting accreditation need to be studied so that they can be applied in other Puskesmas scopes.
\end{abstract}

Purpose - This study aims to examine and analyze the effect of

Diterima : 07 September 2020

Direview : 01 Oktober 2020

Direvisi : 26 Januari 2021

Disetujui : 27 Januari 2021 individual characteristics and leadership skill on organizational performance with Teamwork as an intervening variable at accredited Community Health Centers in Pasuruan district.

Design/Methodology/ApproachThis study examines the effect of individual characteristic and leadership skill on organizational performance with Teamwork skill as an intervening variable at plenary accredited Community Health Center in Pasuruan district. The sample of this study are employees who involved in accreditation process and quality improvement at two plenary accredited Community Health Centers totaling 157 people. Hypothesis testing used Structural Equation Modelling with Partial Least Square regression.

Result and Discussion - The result of this study shows that individual characteristics and leadership skill have significant positive effect toward Teamwork skill. Individual characteristic and leadership skill also have significant positive effect toward organizational performance through Teamwork which means that improvement on individual characteristic and Teamwork skill lead to better organizational performance along with better Teamwork skill. Leadership variable dominantly affects organizational performance through Teamwork skill rather than individual characteristic. Leadership is second order variable with transformational leadership which has dominant measurement toward leadership skill rather than transactional leadership.

Conclusion -The result of this study shows that there is positive and significant effect between individual characteristic and leadership skill toward organizational performance with Teamwork skill as an intervening variable. Leadership skill dominantly affects organizational performance through Teamwork rather than individual characteristic. Leadership is second order variable with transformational leadership dimension which has more dominant effect toward leadership skill rather than transactional leadership.

Research Implication - This research has implications for assessing individual characteristics and leadership, as well as Teamwork on the organizational performance of the health center.

Keywords -Individual, Characteristic, Leadership, Teamwork, Organizational, Performance 


\begin{abstract}
ABSTRAK
Latar Belakang - Berdasarkan pengamatan peneliti selama menjadi pendamping akreditasi pada puskesmas terakreditasi paripurna, beberapa komponen suksesnya puskesmas mendapatkan akreditasi perlu untuk dikaji agar dapat diterapkan di lingkup Puskesmas lainnya.

Tujuan - Untuk menguji dan menganalisis Pengaruh Karakteristik Individu dan Leadership terhadap Kinerja Organisasi dengan Teamwork sebagai Variabel Intervening pada Puskesmas Terakreditasi Paripurna di Kabupaten Pasuruan.

Desain/ Metodologi/ Pendekatan Penelitian mengkaji pengaruh karakteristik individu dan Leadership terhadap Kinerja Organisasi dengan Teamwork sebagai variabel Intervening pada Puskesmas Terakreditasi Paripurna di Kabupaten Pasuruan.Sampel penelitian adalah pegawai yang terlibat dalam proses akreditasi dan peningkatan mutu pelayanan pada 2 puskesmas terakreditasi paripurna sejumlah 157 orang. Pengujian hipotesis menggunakan Structural Equation Modelling dengan Partial Least Square.

Hasil dan Pembahasan- Hasilpenelitian ini, menunjukkan bahwa karakteristik individu dan Leadership memiliki pengaruh positif signifikan terhadap Teamwork. Karakteristik individu dan Leadershipjuga memiliki pengaruh positif signifikan terhadap kinerja organisasi melalui Teamwork artinya semakin baik karakteristik individu dan Teamworkakan berpengaruh terhadap semakin baik kinerja organisasi, seiring dengan semakin baik Teamwork Variabel Leadership berpengaruh paling dominan terhadap kinerja organisasi melalui Teamwork dibandingkan karakteristik individu. Leadership merupakan variabel second order dengan kepemimpinan Transformasional memiliki pengukuran lebih dominan terhadap leadership dibandingkan Kepemimpinan Transaksional.

Kesimpulan -Hasil penelitian ini menunjukkan bahwa terdapat pengaruh yang positif dan signifikan antara Karakteristik Individu dan Leadership terhadap kinerja organisasi dengan Teamwork sebagai variabel intervening. Leadership berpengaruh paling dominan terhadap kinerja organisasi melalui Teamwork dibandingkan karakteristik individu. Leadership merupakan variabel second order dengan dimensi Kepemimpinan Transformasional memiliki pengaruh lebih dominan terhadap Leadership dibandingkan Kepemimpinan Transaksional.

Implikasi Penelitian - Penelitian ini dapat berimplikasi pada menilai Karakteristik Individu dan Leadership, serta Teamwork terhadap Kinerja Organisasi Puskesmas.
\end{abstract}

Kata Kunci - Karakteristik, Individu, Kepemimpinan, Kerjasama, Kinerja, Organisasi

\section{PENDAHULUAN}

Pembangunan kesehatan merupakan bagian integral dan terpenting dalam kerangka pembangunan nasional. Berdasarkan Peraturan Menteri Kesehatan Nomor 43 Tahun 2019, Pusat Kesehatan Masyarakat yang disebut Puskesmas adalah fasilitas pelayanan kesehatan yang menyelenggarakan upaya kesehatan masyarakat dan upaya kesehatan perseorangan tingkat pertama, dengan lebih mengutamakan upaya promotif dan preventif di wilayah kerjanya. Untuk dapat menghasilkan kinerja yang optimal dan berkualitas, serta dapat memuaskan masyarakat, maka seluruh sumberdaya yang ada sebagai input dalam pelayanan harus dikelola secara baik menggunakan prinsip- prinsip manajemen, yang dimulai sejak perencanaan, penggerakan, pelaksanaan, pengendalian, pengawasan dan penilaian untuk menghasilkan output yang efektif dan efisien pada semua kegiatan di Puskesmas dan sesuai standar akreditasi puskesmas dengan predikat paripurna (PermenKes No.46 Tahun 2015).

Menurut Castka et al., 2003 bahwa kinerja organisasi bisa ditingkatkan melalui 
Teamwork yang efektif. Ada beberapa faktor yang mempengaruhi efektivitas Team work yang efektif antara lain leadership. Lebih lanjut disebutkan bahwa keberhasilan seorang leader dalam mengembangkan Teamwork bisa dilakukan dengan cara meningkatkan keterlibatan personal, memotivasi, mendukung, dan memberikan pengakuan terhadap kinerja team serta mengembangkan budaya Teamwork dari budaya kompetisi menjadi budaya kolaboratif. Faktor lain yang berdampak terhadap efektivitas Teamwork adalah karakteristik individu dalam organisasi seperti kemampuan interpersonal yaitu antara lain bisa memaknai konflik untuk kemajuan organisasi, kemampuan berkomunikasi yang baik, kemampuan pencatatan yang efektif, serta kemampuan menganilisis yang baik.

Berdasarkan pengamatan peneliti selama menjadi pendamping akreditasi pada puskesmas terakreditasi paripurna di Kabupaten Pasuruan, yaitu Puskesmas Gondang Wetan dan Puskesmas Gempol, bahwa karakteristik individu yang dimiliki oleh pegawai di ke dua Puskesmas tersebut antara lain ulet, tekun, jujur, berdedikasi tinggi, berakhlak baik, mempunyai keahlian sesuai dibidangnya, kemampuan mengelola konflik, kemampuan berkomunikasi dan berkoordinasi dengan baik, kemampuan menganalisis, serta dapat bekerjasama dalam tim kerja yang solid. Keberhasilan tersebut tidak terlepas dari peran kepemimpinan atau leadership yang baik, mulai Kepala Puskesmas, Kepala Dinas Kesehatan, serta Kepala Pemerintahan Daerah Kabupaten Pasuruan. Karakteristik kepemimpinan yang ditunjukkan adalah antara lain cerdas terampil dalam konseptual, kreatif, diplomatis dan taktis, memiliki kemampuan berkomunikasi dan berkoordinasi yang baik, memiliki pengetahuan tentang tugas kelompok kerja, persuasive, memiliki sebuah kemampuan mengkomunikasikan tujuan atau arah yang dapat menarik perhatian anggota, kemampuan menciptakan dan mengkomunikasikan makna tujuan secara jelas, serta kemampuan untuk dipercaya dan konsisten.

Tujuan penelitian ini adalah untuk menguji dan menganalisis Pengaruh Karakteristik Individu Dan Leadership Terhadap Kinerja Organisasi Dengan Teamwork Sebagai Variabel Intervening Pada Puskesmas Terakreditasi Paripurna Di Kabupaten Pasuruan.

\section{TINJAUAN PUSTAKA}

\section{Karakteristik Individu}

Dalam Kamus Besar Bahasa Indonesia (KBBI) yang dimaksud dengan karakteristik adalah ciri atau sifat yang berkemampuan untuk memperbaiki kualitas hidup. Sedangkan individu adalah perorangan; orang seorang. Berikut adalah pengertian- 
pengertian individual characteristics (karakteristik individu) menurut ahli yaitu :

1. Menurut Panggabean dalam Adi (2008), karakteristik individu merupakan karakter seorang individu yang mempunyai sifat khas sesuai dengan perwatakan tertentu.

2. Menurut Robbins dalam Adi (2008), karakteristik individu adalah cara memandang ke obyek tertentu dan mencoba mengartikan yang dilihatnya.

3. Menurut Hidayat (2013), karakteristik individu yakni ciri khas yang menunjukkan perbedaan seseorang tentang motivasi, inisiatif, kemampuan tetap tegar menghadapi tugas sampai tuntas atau memecahkan masalah atau bagaimana menyesuaikan perubahan yang terkait erat dengan lingkungan yang mempengaruhi kinerja individu.

Menurut John, et al., dalam Purnomo dan Lestari (2010) membagi dimensi kepribadian menjadi lima yaitu: openness to experience, conscientiousness, extraversion, agreeableness dan neuroticism (OCEAN).

1. Kepribadian openness to experience atau keterbukaan terhadap pengalaman hidup antara lain penuh dengan ide baru, imajinasi yang aktif, cerdik dan mendalam, suka refleksi diri, penasaran dengan banyak hal, inovatif, dan artistik. Individu dengan openness to experience yang rendah atau closed to experience memiliki kepribadian yang berkebalikan dari karakter tersebut di atas seperti: tidak inovatif, suka sesuatu yang rutin, praktis, dan cenderung tertutup.

2. Kepribadian conscientiousness atau keterbukaan mata dan telinga antara lain: suka bekerja keras, bekerja sesuai dengan rencana, dapat diandalkan, teratur, melakukan pekerjaan dengan cermat dan terperinci, dan cenderung rajin. Individu dengan kepribadian ini disebut memiliki conscientiousness yang tinggi. Sedangkan individu dengan conscientiousness yang rendah memiliki kepribadian: ceroboh, malas, tidak teratur, dan tidak dapat diandalkan.

3. Kepribadian extraversion atau keterbukaan terhadap orang lain antara lain: aktif berbicara, penuh dengan energi, antusias, kepribadian yang tegas dan pasti, ramah dan suka bergaul. Individu dengan kepribadian ini disebut memiliki extaversion yang tinggi.

4. Agreeableness atau keterbukaan terhadap kesepakatan memiliki kepribadian antara lain: suka bekerja sama, dapat dipercaya, penuh perhatian dan baik pada orang lain, suka menolong, tidak mementingkan diri sendiri, pemaaf, dan tidak suka berselisih dengan orang lain. Individu dengan kepribadian tersebut dikatakan memiliki agreeableness yang tinggi. 
5. Neoriticism atau keterbukaan terhadap tekanan memiliki kepribadian antara lain: sering tertekan, penuh ketegangan dan kekhawatiran, mudah murung, sedih dan gelisah. Individu dengan kepribadian ini dikatakan memiliki emosi yang tidak stabil. Jika sebaliknya, maka individu dapat mengatasi stress dengan baik, tidak mudah kecewa, tenang dalam situasi menegangkan, dan tidak mudah tertekan.

\section{Leadership/Kepemimpinan}

Alam et al., (2013) menjelaskan dalam kepemimpinan itu terdapat hubungan antara manusia yaitu, hubungan mempengaruhi maksudnya adalah orang dikenal oleh dan berusaha mempengaruhi para pengikutnya untuk merealissasi visinya. Kepemimpinan didalamnya ada hubungan antara manusia yaitu, hubungan memengaruhi dari pemimpin dan hubungan kepatuhan-ketaatan para pengikut karena dipengaruhi oleh kewibawaan pemimpin. Para pengikut terkena pengaruh kekuatan dari pemimpinnya, dan bangkitlah secara spontan rasa ketaatan pada pemimpin. Kepemimpinan transformasional menurut Bass (2006) memiliki karakteristik yang membedakan dengan gaya kepemimpinan yang lainnya di antaranya :

1. Charisma

Memberikan visi dan misi yang masuk akal, menimbulkan kebanggaan, menimbulkan rasa hormat dan percaya

\section{Inspiration}

Mengkomunikasikan harapan yang tinggi, menggunakan simbol untuk memfokuskan upaya, mengekspresikan tujuan penting dengan cara sederhana.

3. Intellectual stimulation

Peningkatan intelegensia, rasionalitas, dan pemecahan masalah secara teliti.

4. Individualized consideration

Memberikan perhatian pribadi, melakukan pelatihan dan konsultasi kepada bawahan secara individual.

Burns mendefinisikan kepemimpinan transaksional adalah kepemimpinan yang memotivasi bawahan atau pengikut dengan minat-minat pribadinya. Kepemimpinan transaksional juga melibatkan nilai-nilai akan tetapi nilai-nilai itu relevan sebatas proses pertukaran (exchange process), tidak langsung menyentuh substansi perubahan yang dikehendaki (Abdul, 2011) mengemukakan kepemimpinan transaksional dapat digambarkan sebagai :

1. Mempertukarkan sesuatu yang berharga bagi yang lain antara pemimpin dan bawahannya.

2. Intervensi dilakukan sebagai proses organisasional untuk mengendalikan dan memperbaiki kesalahan.

3. Reaksi atas tidak tercapainya standar yang telah ditentukan.

Bass (2006) mengemukakan kepemimpinan transaksional adalah kepemimpinan di mana pemimpin 
menentukan apa yang harus dikerjakan oleh karyawan agar mereka dapat mencapai tujuan mereka sendiri atau organisasi dan membantu karyawan agar memperoleh kepercayaan dalam mengerjakan tugas tersebut. Jadi kepemimpinan transaksional merupakan sebuah kepemimpinan dimana seorang pemimpin mendorong bawahannya untuk bekerja dengan menyediakan sumberdaya dan penghargaan sebagai imbalan untuk motivasi, produktivitas dan pencapaian tugas efektif. Kepemimpinan transaksional menurut Bass (2006) memiliki karakteristik sebagai berikut :

\section{Contingent reward}

Kontrak pertukaran penghargaan untuk usaha, penghargaan dijanjikan untuk kinerja yang baik sebagai pencapaian.

2. Active management by exception

Melihat dan mencari penyimpangan dari aturan atau standar, mengambil tindakan perbaikan.

3. Pasive management by exception Intervensi jika standar tidak tercapai

4. Laissez-faire

Melepaskan tanggung jawab, menghindari pengambilan keputusan.

\section{Pusat Kesehatan Masyarakat (Puskesmas)}

Berdasarkan Peraturan Menteri Kesehatan Nomor 43 tentang Puskesmas Tahun 2019 Pusat Kesehatan Masyarakat yang selanjutnya disebut Puskesmas adalah fasilitas pelayanan kesehatan yang menyelenggarakan upaya kesehatan masyarakat dan perseorangan tingkat pertama, dan lebih mengutamakan upaya promotif dan preventif di wilayah kerjanya.

Pembangunan kesehatan yang diselenggarakan Puskesmas bertujuan untuk mewujudkan wilayah kerja Puskesmas sehat, dengan masyarakat yang:

1. Memiliki perilaku sehat yang meliputi kesadaran, kemauan, dan kemampuan hidup sehat

2. Mampu menjangkau Pelayanan Kesehatan bermutu

3. Hidup dalam lingkungan sehat

4. Memiliki derajat kesehatan yang optimal, baik individu, keluarga, kelompok, dan masyarakat

Pelayanan Kesehatan Puskesmas yang disebut dengan Pelayanan Kesehatan adalah upaya yang diberikan Puskesmas pada masyarakat, mencakup perencanaan, pelaksanaan, evaluasi, pencatatan, dan pelaporan yang dituangkan dalam suatu sistem. Akreditasi Puskesmas adalah pengakuan terhadap mutu pelayanan Puskesmas, setelah dilakukan penilaian bahwa Puskesmas telah memenuhi standar akreditasi sesuai dengan Peraturan Menteri Kesehatan No.46 tahun 2015 Akreditasi Puskesmas, Klinik Pratama, Tempat Praktek Mandiri dokter dan dokter gigi. Puskesmas yang terakreditasi, harus dilakukan survey akreditasi oleh Komisi Akreditasi Fasilitas Kesehatan Tingkat Pertama (FKTP) setiap 3 tahun sekali. 


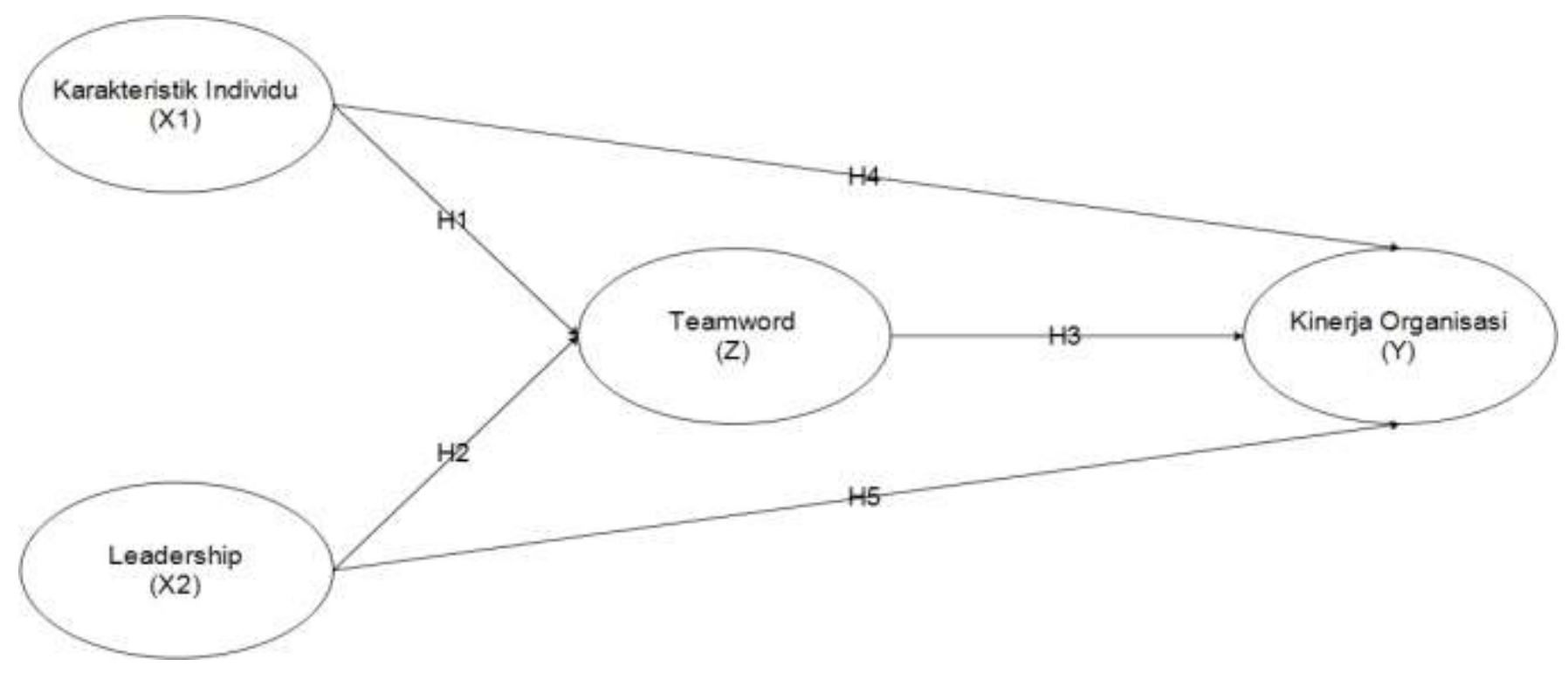

Gambar. 1. Kerangka Penelitian

\section{Hipotesis}

Faktor individu atau individual characteristics (karakteristik individu) adalah karakter seorang individu atau ciriciri seseorang yang menggambarkan keadaan individu tersebut yang sebenarnya dan membedakannya dari individu lain. Hal ini sejalan dengan penelitian Pratiwi dan Nugrohoseno (2014) dengan hasil penelitian menunjukkan bahwa kepribadian berpengaruh positif dan signifikan terhadap kerjasama tim. Menurut Winardi dalam Hidayat (2013), karakteristik individu mencakup sifat-sifat berupa kemampuan dan keterampilan; latar belakang keluarga, sosial, dan pengalaman, umur, bangsa, jenis kelamin dan lain yang mencerminkan sifat demografis tertentu serta karakteristik psikologis yang terdiri dari persepsi, sikap, kepribadian, belajar, dan motivasi. Cakupan sifat-sifat tersebut membentuk suatu nuansa budaya tertentu menandai ciri dasar bagi suatu organisasi tertentu. Menurut Ardana (2009) karakteristik individu meliputi (1) minat, (2) sikap tehadap diri sendiri, pekerjaan, dan situasi pekerjaan, (3) kebutuhan individual, (4) kemampuan dan toleransi, dan (5) pengetahuan tentang pekerjaan.

Menurut pengamatan peneliti, Pegawai yang ada di Purkesmas terakreditasi Paripurna di Kabupaten Pasuruan memiliki ciri-ciri atau karakteristik yakni (1) Memiliki pengetahuan penuh tentang tugas, tanggung jawab dan wewenangnya (2) Memiliki pengetahuan (knowledges) yang diperlukan, terkait dengan pelaksanaan tugasnya secara penuh, (3) Mampu melaksanakan tugas-tugas yang harus dilakukannya karena mempunyai keahlian ketrampilan (skills) yang diperlukan, dan (4) Bersikap produktif, inovatif/ kreatif, mau 
bekerjasama dengan orang lain, dapat dipercaya, loyal dan sebagainya.

Teamwork memiliki kemampuan untuk memungkinkan anggota tim memiliki tingkat keamanan emosional yang lebih tinggi, kepercayaan diri, dan kemampuan untuk merencanakan dan memutuskan dengan orang lain secara positif, serta membantu dalam menciptakan lingkungan kerja yang sehat dengan agenda yang dapat dikerjakan, kegiatan kreatif, strategi dan nilai positif. Dalam hal ini sejalan dengan hasil penelitian Putri dan Sariyathi (2017) yang menunjukkan bahwa semua kerjama tim berpengaruh positif dan signifikan terhadap kinerja karyawan serta berdampak terhadap kinerja organisasi. Maka dapat disimpulan hipotesis penelitian pertama.

\section{H1: Karakteristik Individu mempunyai pengaruh yang positif dan signifikan terhadap Teamwork}

Kepemimpinan merupakan salah satu aset yang dimiliki organisasi yang menjadi salah satu kekuatan untuk mencapai kesuksesan organisasi. Kepemimpinan yang efektif diyakini merupakan faktor yang mempengaruhi juga prestasi para pegawai dalam suatu organisasi (Abdul, 2011). Salah satu faktor penting yang memengaruhi keberhasilan proses kepemimpinan adalah perilaku pemimpin yang bersangkutan atau gaya pemimpin/gaya kepemimpinan (leadership style). Beberapa tahun terakhir, upaya pembenahan dan penyempurnaan kinerja organisasi khususnya organisasi Puskesmas menjadi sesuatu hal yang sangat penting untuk segera dilakukan. Hal ini disebabkan karena adanya tuntutan terhadap mutu pelayanan kesehatan sebagai konsekuensi langsung dari perkembangan ilmu pengetahuan dan teknologi yang begitu pesat. Dalam bidang kesehatan khususnya pelayanan di puskesmas, kepuasan pelanggan atas pelayanan yang diberikan merupakan fokus tujuan, pelayanan kesehatan yang berkualitas sesuai standar melalui akreditasi puskesmas dengan predikat paripurna tidak mungkin tercapai tanpa adanya kinerja organisasi yang baik.

Teamwork merupakan faktor penting untuk kelancaran fungsi fungsi organisasi. Sebagian besar kegiatan organisasi menjadi kompleks karena kemajuan teknologi sehingga Teamwork merupakan fokus utama banyak perusahaan atau organisasi (Sinambela, 2016). Saptiani dan Gilang (2017) mendefinisan Teamwork sebagai sekelompok individu yang bekerja secara kolektif untuk mencapai tujuan dan sasaran yang sama untuk memberikan kualitas layanan yang baik dalam organisasi. Dengan demikian dapat disimpulan hipotesis penelitian kedua.

H2: Leadership/ Kepemimpinan
mempunyai pengaruh yang positif dan
signifikan terhadap Teamwork


Teamwork memiliki kemampuan untuk memungkinkan anggota tim memiliki tingkat keamanan emosional yang lebih tinggi, kepercayaan diri, dan kemampuan untuk merencanakan dan memutuskan dengan orang lain secara positif, serta membantu dalam menciptakan lingkungan kerja yang sehat dengan agenda yang dapat dikerjakan, kegiatan kreatif, strategi dan nilai positif. Dalam hal ini sejalan dengan hasil penelitian Putri dan Sariyathi (2017) yang menunjukkan bahwa semua kerjama tim berpengaruh positif dan signifikan terhadap kinerja karyawan serta berdampak terhadap kinerja organisasi.

Konsep kinerja (performance) dapat didefenisikan sebagai sebuah pencapaian hasil atau degree of accomplishment (Rue dan Byars, 1981 dalam Keban 1995) Hal ini berarti bahwa kinerja suatu organisasi itu dapat dilihat dari tingkatan sejauh mana organisasi dapat mencapai tujuan yang didasarkan pada tujuan yang sudah ditetapkan sebelumnya. Menurut Wibowo, (2011) menjelaskan bahwa: "Kinerja organisasional merupakan produk dari banyak faktor, termasuk struktur organisasi, pengetahuan, sumberdaya bukan manusia, posisi strategis, dan proses sumber daya manusia. Kinerja memerlukan strategi, tujuan, dan integrasi. Dengan demikian dapat disimpulan hipotesis penelitian ketiga, keempat, dan kelima.
H3: Teamwork mempunyai pengaruh yang positif dan signifikan terhadap Kinerja Organisasi

H4: Karakteristik Individu mempunyai pengaruh yang positif dan signifikan terhadap Kinerja Organisasi melalui Teamwork

H5: Leadership/ Kepemimpinan mempunyai pengaruh yang positif dan signifikan terhadap Kinerja Organisasi melalui Teamwork

\section{METODOLOGI PENELITIAN}

Penelitian ini merupakan penelitian kausalitas. Populasi penelitian ini adalah seluruh pegawai yang ada di 2 (dua) Puskesmas terakreditasi paripurna di Kabupaten Pasuruan (Puskesmas Gondang Wetan dan Puskesmas Gempol) berjumlah 157 orang. Teknik pengambilan sampel menggunakan Purposive Sampling, yaitu teknik penentuan sampel dengan pertimbangan tertentu atau disertakan kriteria sehingga layak dijadikan sampel (Sugiyono, 2010). Sampel penelitian ini adalah Pegawai yang terlibat dalam Tim Akreditasi Puskesmas yang berjumlah 106 orang. Data yang digunakan dalam penelitian ini adalah data primer dan data sekunder. Data primer yaitu data yang diperoleh dari hasil penelitian langsung di lapangan atau berasal dari sumber data terhadap pegawai UPTD Kesehatan di Puskesmas Gondang Wetan dan Puskesmas 
Gempol (Sugiyono, 2010). Sedangkan data sekunder adalah data yang diperoleh peneliti dari sumber yang sudah ada.

Pengumpulan data sekunder pada penelitian ini antara lain bersumber dari Dokumen Renstra Dinas Kesehatan kabupaten Pasuruan Tahun 2018-2023, Dokumentasi Puskesmas, Data Profil Kesehatan, dan Laporan Hasil Penilaian Kinerja Puskesmas Gondang Wetan dan Puskesmas Gempol Kabupaten Pasuruan Tahun 2019.
Berdasarkan hasil pengujian model variabel laten dalam penelitian ini, dikelompokkan menjadi dua kelompok yaitu variabel eksogen dan variabel endogen. Variabel eksogen yaitu variabel Kepemimpinan (LD) dan Karakteristik Individu (KI). Variabel endogen yaitu Teamwork (TW) dan Kinerja Organisasi (KO). Model dikatakan baik bila pengembangan model hipotesis secara teoritis didukung oleh data empirik. Hasil analisis dengan Partial Least Square (PLS) untuk mengetahui pengaruh antar variabel secara lengkap dapat dilihat pada gambar 2 .

\section{HASIL DAN PEMBAHASAN}

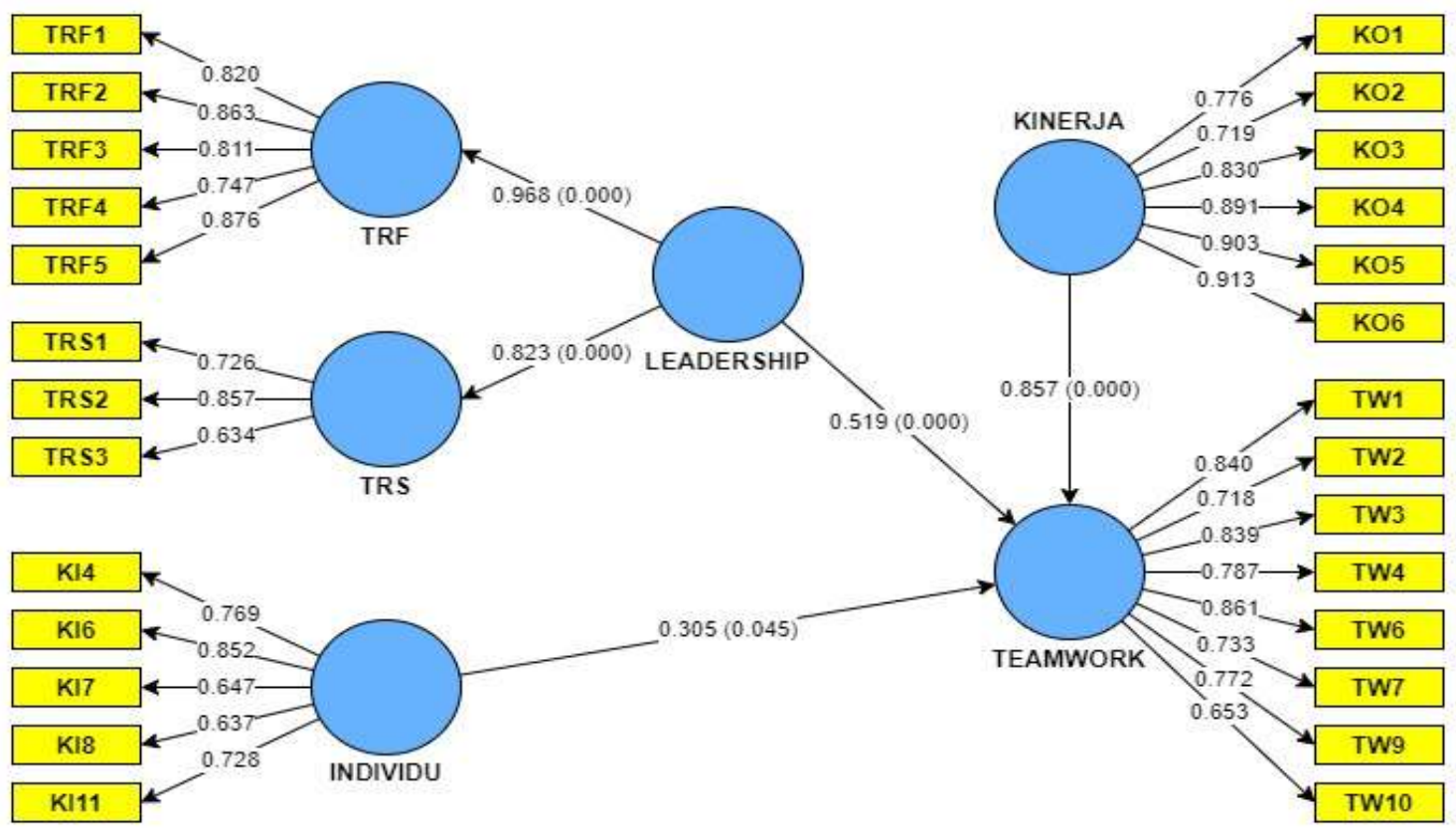

Gambar 2. Hasil Penelitian dengan Partial Least Square

Berdasarkan Gambar 2, terdapat 4 variabel yaitu variabel Kepemimpinan (LD), Karakteristik Individu (KI), Teamwork (TW), dan Kinerja Organisasi (KO) dengan pengukuran reflektif. Variabel Kepemimpinan merupakan variabel second order yang diukur dari dimensi Kepemimpinan Transformasional (TRF) dan Kepemimpinan Transaksional (TRS). Hasil dari pengukuran second order diperoleh nilai koefisien untuk Kepemimpinan Transformasional sebesar 0,968 dan 
Kepemimpinan Transaksional sebesar 0,823 yang artinya bahwa Kepemimpinan Transformasional memiliki pengukuran lebih dominan terhadap variabel Kepemimpinan. Pengaruh terhadap Teamwork dijelaskan oleh variabel Kepemimpinan dan Karakteristik Individu dengan koefisien jalur bernilai positif, artinya semakin baik Kepemimpinan dan Karakteristik Individu akan berpengaruh terhadap semakin baik Teamwork. Kemudian pengaruh terhadap Kinerja Organisasi dijelaskan oleh variabel Kepemimpinan, Karakteristik Individu, dan Teamwork dengan koefisien jalur bernilai positif, artinya semakin baik Kepemimpinan, Karakteristik Individu, dan Teamwork akan berpengaruh terhadap semakin baik Kinerja Organisasi.

Tabel 1

Pengujian Hipotesis

\begin{tabular}{|c|l|r|r|r|l|}
\hline \multirow{2}{*}{ Hipotesis } & \multicolumn{1}{c|}{ Koefisien } & \multicolumn{1}{c|}{ Jalur } & \multicolumn{1}{c|}{ Statistics } & \multicolumn{1}{c|}{-value } & \multicolumn{1}{c|}{ Ket. } \\
\hline H1 & Karakteristik Individu $\rightarrow$ Teamwork & 0.305 & 2.007 & 0.045 & Signifikan \\
\hline H2 & Leadership $\rightarrow$ Team work & 0.519 & 4.806 & 0.000 & Signifikan \\
\hline H3 & Teamwork $\rightarrow$ Kinerja & 0.857 & 26.781 & 0.000 & Signifikan \\
\hline H4 & Leadership $\rightarrow$ Kinerja & 0.445 & 4.727 & 0.000 & Signifikan \\
\hline H5 & Karakteristik Individu $\rightarrow$ Kinerja & 0.261 & 2.000 & 0.046 & Signifikan \\
\hline
\end{tabular}

Sumber: Data primer diolah (2020)

\section{Hasil Pengujian Hipotesis}

\section{H1: Karakteristik Individu terhadap}

\section{Teamwork}

Hipotesis pengaruh antara variabel karakteristik individu terhadap variabel Teamwork diperoleh koefisien jalur sebesar 0,305 dengan nilai $\mathrm{t}$ statistik 2,007 (t > 1,960) dan $\mathrm{p}$-value sebesar $0,045(\mathrm{p}<0,05)$ sehingga variabel karakteristik individu memiliki pengaruh positif signifikan terhadap variabel Teamwork artinya semakin baik karakteristik individu akan berpengaruh terhadap semakin baik Teamwork. Hasil tersebut menunjukkan bahwa hipotesis diterima.

\section{H2: Leadership/ Kepemimpinan} terhadap Teamwork

Hipotesis pengaruh antara variabel kepemimpinan terhadap variabel Teamwork diperoleh koefisien jalur sebesar 0,519 dengan nilai t statistik $4,806$ ( $\mathrm{t}>1,960)$ dan $\mathrm{p}$-value sebesar $0,000(\mathrm{p}<0,05)$ sehingga variabel kepemimpinan memiliki pengaruh positif signifikan terhadap variabel Teamwork artinya semakin baik kepemimpinan akan berpengaruh terhadap semakin baik Teamwork. Hasil tersebut menunjukkan bahwa hipotesis diterima. 


\section{H3: Teamwork terhadap Kinerja Organisasi}

Hipotesis pengaruh antara variabel Teamwork terhadap variabel kinerja organisasi diperoleh koefisien jalur sebesar 0,857 dengan nilai $\mathrm{t}$ statistik 26,781 (t > 1,960) dan p-value sebesar $0,000(\mathrm{p}<0,05)$ sehingga variabel Teamwork memiliki pengaruh positif signifikan terhadap variabel kinerja organisasi artinya semakin baik Teamwork akan berpengaruh terhadap semakin baik kinerja organisasi. Hasil tersebut menunjukkan bahwa hipotesis diterima.

\section{H4: Karakteristik Individu terhadap} Kinerja Organisasi melalui Teamwork Hipotesis pengaruh antara variabel karakteristik individu terhadap variabel kinerja organisasi diperoleh koefisien jalur sebesar 0,261 dengan nilai $t$ statistik 2,000 (t > 1,960) dan p-value sebesar 0,046 (p<0,05) sehingga variabel karakteristik individu memiliki pengaruh positif signifikan terhadap variabel kinerja organisasi melalui Teamwork artinya semakin baik karakteristik individu dapat berpengaruh terhadap semakin baik kinerja organisasi seiring dengan semakin baik Teamwork. Hasil tersebut menunjukkan bahwa hipotesis diterima.

\section{H5: Leadership/ Kepemimpinan terhadap Kinerja Organisasi melalui Teamwork}

Hipotesis pengaruh antara variabel kepemimpinan terhadap variabel kinerja organisasi diperoleh koefisien jalur sebesar 0,445 dengan nilai $t$ statistik 4,727 (t > 1,960) dan p-value sebesar $0,000(\mathrm{p}<0,05)$ sehingga variabel kepemimpinan memiliki pengaruh positif signifikan terhadap variabel kinerja organisasi melalui Teamwork artinya semakin baik kepemimpinan akan berpengaruh terhadap semakin baik kinerja organisasi seiring dengan semakin baik Teamwork. Hasil tersebut menunjukkan bahwa hipotesis diterima.

\section{Hasil Pengujian PLS}

1. Karakteristik Individu terhadap Teamwork

Hasil analisis partial least square pada penelitian ini menunjukkan variabel karakteristik individu memiliki pengaruh positif signifikan terhadap variabel Teamwork artinya semakin baik Teamwork akan berpengaruh terhadap semakin baik Teamwork di Puskesmas terakreditasi Paripurna di Kabupaten Pasuruan. Hal tersebut dibuktikan dengan hasil pengujian koefisien jalur sebesar 0,857 dengan nilai t statistik 26,781 ( $>1$,960) dan $\mathrm{p}$ - 
value sebesar $0,000(\mathrm{p}<0,05)$. Indikator-indikator karakteristik individu yang berpengaruh terhadap Teamwork di Puskesmas terakreditasi paripurna dari hasil penelitian ini antara lain kemampuan bekerja sama dengan rekan kerja dalam menjalankan tugas dan merencanakan tujuan dan mengidentifikasi kompetensi yang hendak dicapai, keahlian individu dalam berinteraksi dalam melakukan pekerjaan dan mengelola kearsipan dokumen, Pengalaman administrasi setiap kali melakukan tugas pokok dan fungsinya, Keterampilan individu dalam melaksanakan berbagai tugas yang diberikan atasan, serta Keprofesian individu.

2. Leadership/Kepemimpinan terhadap Teamwork

Hasil analisis partial least square pada penelitian ini juga menunjukkan bahwa variabel Leadership/kepemimpinan memiliki pengaruh positif signifikan terhadap variabel Teamwork artinya semakin baik kepemimpinan akan berpengaruh terhadap semakin baik Teamwork di Puskesmas Terakreditasi Paripurna di Kabupaten Pasuruan. Hal tersebut dibuktikan dengan hasil koefisien jalur sebesar 0,519 dengan nilai $t$ statistik 4,806 ( $>1,960)$ dan $\mathrm{p}$ value sebesar $0,000(\mathrm{p}<0,05)$.
Dalam penelitian ini variabel Kepemimpinan merupakan variabel second order yang diukur dari dimensi Kepemimpinan Transformasional (TRF) dan Kepemimpinan Transaksional (TRS). Hasil dari pengukuran second order diperoleh nilai koefisien untuk Kepemimpinan Transformasional sebesar 0,968 dan Kepemimpinan Transaksional sebesar 0,823 yang artinya bahwa Kepemimpinan Transformasional memiliki pengukuran lebih dominan terhadap variabel Kepemimpinan. Hal tersebut menunjukkan bahwa gaya kepemimpinan yang paling dominan mempengaruhi Teamwork di Puskesmas terakreditasi Paripurna di Kabupaten Pasuruan adalah gaya kepemimpiran transformasional dengan Indikator-indikator antara lain: pemimpin yang mempertimbangkan kebutuhan, kemampuan, aspirasi dan partisipasi dari anggota kelompok untuk melancarkan komunikasi antar pegawai, pemimpin selalu mempertimbangkan konsekuensi moral dan etika dalam pengambilan keputusan, pemimpin lebih mengutamakan kepentingan kelompok daripada kepentingan pribadi, dan merupakan Role Model (panutan) dalam organisasi, pemimpin menunjukkan dan memberikan keyakinan bahwa 
berbagai tujuan organisasi akan tercapai, serta memberikan motivasi kepada anggota organisasi untuk bekerja lebih baik, pemimpin dapat menyelesaikan masalah dari berbagai sudut pandang.

3. Teamwork terhadap Kinerja Organisasi Hasil analisis partial least square pada penelitian ini juga menunjukkan bahwa variabel Teamwork memiliki pengaruh positif signifikan terhadap variabel kinerja organisasi artinya semakin baik Teamwork akan berpengaruh terhadap semakin baik kinerja organisasi Puskesmas terakreditasi paripurna di Kabupaten Pasuruan. Hal tersebut dibuktikan dengan hasil koefisien jalur sebesar 0,857 dengan nilai t statistik 26,781 ( $\mathrm{t}>1,960$ ) dan $\mathrm{p}$-value sebesar $0,000(\mathrm{p}<0,05)$. Indikator-indikator Teamwork yang berpengaruh terhadap kinerja organisasi puskesmas terakreditasi paripurna di Kabupaten Pasuruan antara lain setiap anggota tim memiliki andil yang kuat terhadap keberhasilan tim, anggota tim secara bersama-sama bertanggungjawab terhadap kualitas kerja organisasi, anggota tim bekerja bersama-sama saat menjalankan tugas, dalam menjalankan tugas, anggota tim saling berkontribusi, pimpinan menerima dengan puas terhadap hasil pekerjaan tim, pembagian tugas dibangun atas dasar kepercayaan akan kemampuan anggota tim, kerja tim yang dibangun merupakan komitmen bersama dalam mencapai tujuan yang akan dicapai, hasil kerja tim bukanlah merupakan semata-mata kemampuan individual tetapi hasil kontribusi semua anggota tim kerja.

4. Karakteristik Individu terhadap Kinerja Organisasi melalui Teamwork

Hasil analisis partial least square pada penelitian ini juga menunjukkan bahwa variabel karakteristik individu memiliki pengaruh positif signifikan terhadap variabel kinerja organisasi melalui Teamwork artinya semakin baik karakteristik individu akan berpengaruh terhadap semakin baik kinerja organisasi Puskesmas terakreditasi Paripurna, seiring dengan semakin baik Teamwork. Hal tersebut dibuktikan dengan hasil pengujian pengaruh antara variabel karakteristik individu terhadap variabel kinerja organisasi diperoleh koefisien jalur sebesar 0,261 dengan nilai $t$ statistik 2,000 ( $\mathrm{t}>1,960$ ) dan $\mathrm{p}$-value sebesar $0,046(\mathrm{p}<0,05)$

5. Leadership/Kepemimpinan terhadap Kinerja Organisasi melalui Teamwork Hasil analisis partial least square pada penelitian ini menunjukkan bahwa variabel Leadership/ kepemimpinan memiliki pengaruh positif signifikan 
terhadap variabel kinerja organisasi melalui Teamwork artinya semakin baik kepemimpinan akan berpengaruh terhadap semakin baik kinerja organisasi seiring dengan semakin baik Teamwork. Pengaruh antara variabel Leadership/ kepemimpinan terhadap variabel kinerja organisasi dibuktikanghmb dengan koefisien jalur sebesar 0,445 dengan nilai $\mathrm{t}$ statistik 4,727 (t > 1,960) dan p-value sebesar $0,000(\mathrm{p}<0,05)$. Hal tersebut sesuai dengan hasil penelitian Castka, 2003 bahwa kinerja organisasi bisa ditingkatkan melalui Teamwork yang efektif. Ada beberapa faktor yang mempengaruhi efektivitas Team work yang efektif antara lain leadership.

\section{Variabel Dominan Mempengaruhi}

Dari hasil analisis partial least square pada penelitian ini sesuai tabel 25. menunjukkan bahwa untuk pengaruh terhadap Teamwork, variabel karakteristik individu memiliki koefisien jalur sebesar 0,305 dan variabel leadership/ kepemimpinan memiliki koefisien jalur sebesar 0,519. Variabel dominan dilihat dari koefisien jalur paling besar, sehingga variabel leadership memiliki pengaruh dominan terhadap Teamwork dibandingkan dengan variabel karakteristik individu. Variabel Leadership/ Kepemimpinan merupakan variabel second order diukur dari dimensi Kepemimpinan Transformasional (TRF) dan Kepemimpinan
Transaksional (TRS). Hasil dari pengukuran second order diperoleh nilai koefisien untuk Kepemimpinan Transformasional sebesar 0,968 dan Kepemimpinan Transaksional sebesar 0,823 yang artinya bahwa Kepemimpinan Transformasional memiliki pengukuran lebih dominan terhadap variabel Kepemimpinan dibandingkan Kepemimpinan Transaksional.

Sedangkan untuk pengaruh terhadap Kinerja Organisasi melalui Teamwork, variabel Karakteristik individu memiliki koefisien jalur sebesar 0.261 dan variabel leadership/ kepemimpinan memiliki koefisien jalur sebesar 0.445 artinya menunjukkan bahwa variabel Leadership memiliki pengaruh paling dominan terhadap Kinerja Organisasi melalui Teamwork dibandingkan dengan variabel karakteristik Individu.

\section{KESIMPULAN}

Sumber daya manusia (SDM) adalah salah satu faktor yang sangat penting bahkan tidak dapat dilepaskan dari sebuah organisasi. SDM berupa manusia yang dipekerjakan di sebuah organisasi sebagai penggerak, pemikir dan perencana untuk mencapai tujuan organisasi itu, begitu juga untuk organisasi Puskesmas Terakreditasi Paripurna di Kabupaten Pasuruan. Berdasarkan Profil Kesehatan Dinas Kabupaten Pasuruan Tahun 2019, terdapat 2 (dua) Puskesmas yang berhasil mendapatkan predikat akreditasi Paripurna 
dari 33 Puskesmas di Kabupaten Pasuruan yaitu Puskesmas Gondang Wetan dan Puskesmas Gempol.

Pada Penelitian ini Pengaruh terhadap Teamwork dijelaskan oleh variabel Karakteristik Individu dan Leadership/ Kepemimpinan dengan koefisien jalur bernilai positif, artinya semakin baik Leadership dan Karakteristik Individu akan berpengaruh terhadap semakin baik Teamwork. Kemudian pengaruh terhadap Kinerja Organisasi dijelaskan oleh variabel Karakteristik Individu dan Leadership/ Kepemimpinan dengan Teamwork sebagai variabel intervening dengan koefisien jalur bernilai positif, artinya semakin baik Karakteristik Individu dan Kepemimpinan melalui Teamwork dapat berpengaruh terhadap Kinerja organisasi Puskesmas Terakreditasi Paripurna di Kabupaten Pasuruan.

Leadership memiliki pengaruh dominan terhadap Teamwork dibandingkan dengan karakteristik individu. Leadership/ Kepemimpinan juga berpengaruh dominan terhadap kinerja organisasi melalui Teamwork dibandingkan karakteristik individu. Leadership merupakan variabel second order yang diukur dari dimensi Kepemimpinan Transformasional dan Kepemimpinan Transaksional. Hasil dari pengukuran second order menunjukkan bahwa Kepemimpinan Transformasional memiliki pengaruh dominan terhadap variabel Kepemimpinan dibandingkan Kepemimpinan Transaksional pada Puskesmas Terakreditasi paripurna di Kabupaten Pasuruan.

\section{IMPLIKASI PENELITIAN}

Penelitian ini dapat memberikan referensi dalam mengidentifikasi dan mengelola karakteristik individu, Leadership, serta teamwork dalam meningkatkan kinerja organisasi khususnya organisasi puskesmas dalam upaya mencapai akreditasi dengan predikat paripurna.

\section{ACKNOWLEDGEMENT}

Penulis mengucapkan terima kasih kepada Kepala Puskesmas dan Pegawai Puskesmas Gondang Wetan dan Puskesmas Gempol serta Dinas Kesehatan Kabupaten Pasuruan atas izin survey dan pengambilan data sehingga penelitian ini dapat terselesaikan dengan baik.

\section{DAFTAR PUSTAKA}

Abdul, Hameed. 2011. Employee Development and Its Affect on Employee Performance A Conceptual Frame work. International Journal of Business and Social Science, 2(13): 224229.

Adi, Prasetyo, 2008. "Analisis Pengaruh Kualitas Pelayanan Terhadap Kepuasan Nasabah BMT Kaffah Yogyakarta”, Surakarta, Skripsi FE STAIN. 
Alam, Titah Mustika., Alsabji, Taher., dan Raharjo, Kusdi. 2013. Pengaruh Gaya Kepemimpinan Transformasional dan Budaya Organisasi Terhadap Kepuasan Kerja Pegawai (Studi Pada Pegawai Kantor Pusat PT Pelabuhan Indonesia III (Persero) Surabaya. Jurnal Administrasi Bisnis, 2(2): 1-6

Ardana, Komang. 2009. Perilaku Keorganisasian. Yogyakarta: Graha Ilmu.

Bass, B. M., Riggio, R.E; 2006 Transformational Leadership. Lawrence Erlbaum Associates, Publishers. Marwah New Jersey. London

Castka, Sharp, dan Bamber. 2003. Assessing Teamwork Development to Improve Organizational Performance. Vol.7 No.4.2003.pp.29-36@MCB UP Limited, ISSN 136-3047.

Hidayat, Rachmad, 2013. Pengaruh Kepemimpinan terhadap Komunikasi, Kepuasan Kerja, dan Komitmen Organisasi pada Industri Perbankan Teknik Industri. Universitas Trunojoyo, Kamal Bangkalan, Madura 16912, Indonesia Makara Seri Sosial Humaniora, 2013, 17(1): 19-32 DOI: 10.7454/mssh.v17i1.1799.

Keban, Jeremias T”. 1995. Indikator Kinerja Pemerintah Daerah. Yogyakarta: UGM

Pratiwi, W. K., \& Nugrohoseno, D. 2014. Pengaruh kepribadian terhadap kerjasama tim dan dampaknya terhadap kinerja karyawan. Jurnal Ilmu Manajemen vol. 5, 1117-1129

Putri, Luh De Puryatini dan Sariyathi, Ni Ketut. 2017. Pengaruh Gaya Kepemimpinan Transformasional, Kerjasama Tim, dan Komunikasi Terhadap Kinerja Karyawan Warung Mina Cabang Renon

Purnomo, R., dan Lestari, S. (2010). Pengaruh Kepribadian, Self-Efficacy, dan Locus of Control Terhadap Persepsi Kinerja Usaha Skala Kecil dan Menengah. Jurnal Bisnis Dan Ekonomi, 17(2).

Peraturan Menteri Kesehatan No. 46 Tahun 2015 Tentang Akreditasi Puskesmas, Klinik Pratama, Tempat Praktik Mandiri Dokter, dan Tempat Praktik Mandiri Dokter Gigi.

Saptiani, D dan Gilang, A. (2017) The Influence Of Teamwork On Employee Performance (In State-Owned Enterprise In Bandung, Indonesia)

Sarboini, Jen Surya, Wahyu Safiansyah. 2017. Pengaruh Kepemimpinan dan Team Work Terhadap Kinerja Pegawai Pada PT. PLN (PERSERO) Cabang Banda Aceh Jurnal Ekonomi dan Manajemen Teknologi (EMT) 1(2), 2017,86-90

Sinambela, L. P. (2016). Human Resource Management Built solid Teamwork to increase performance. Jakarta: Bumi Aksara

Sugiyono. (2010). Metode Penelitian Kuantitatif, Kualitatif dan R\&D. Bandung: Alfabeta.

Wibowo. (2011). Manajemen Kinerja. Edisi Ketiga. Jakarta: PT Raja Grafindo Persada. 